
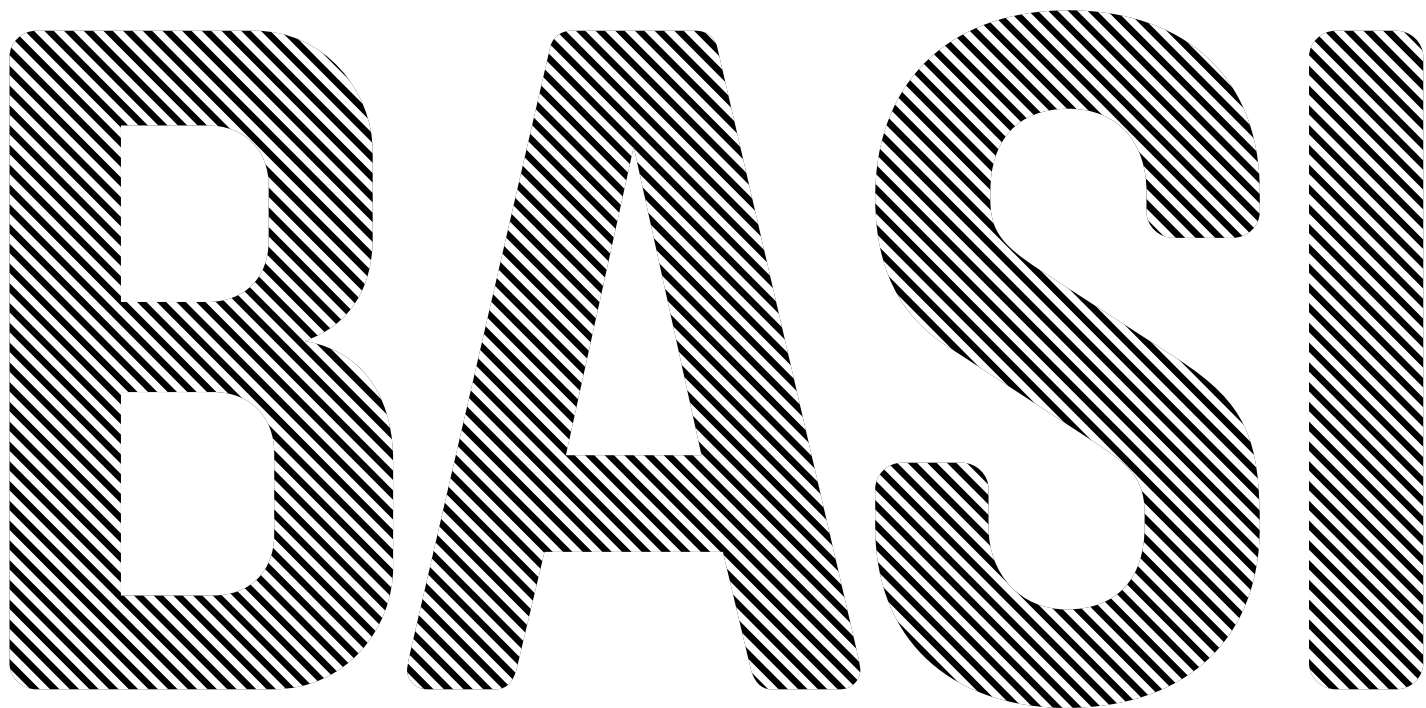

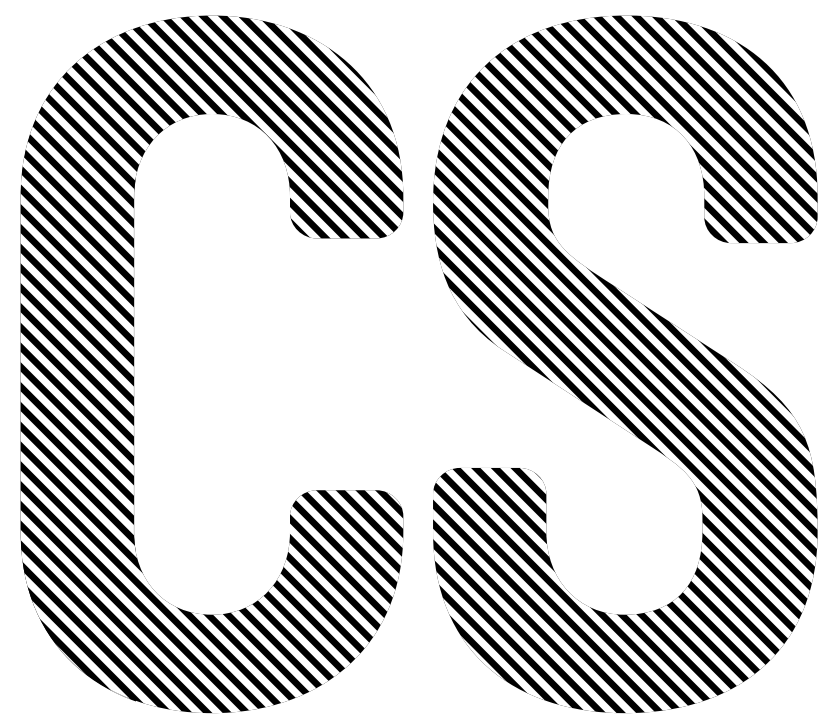

\section{Ludwig Steiger}

Timber

Construction

Third edition

BIRKHÄUSER

BASEL 
